\section{HindllI RFLP at the human IFNAR locus}

E.Vielh, G.Uzé, G.Lutfalla, M.T.Bandu and

K.E.Mogensen

Laboratoire d'Oncologie Virale, CNRS UPR 274, 7, rue

Guy Môquet, 94801 Villejuif Cedex, France

Source/Description: A 195 bp EcoRI-SalI fragment 19ES was used as an hybridization probe. It derives from a cDNA for the gene IFNAR which encodes the human interferon alpha receptor (1) (GenBank Accession Number J03171), and contains upstream non-coding and coding sequences (amino-acids 1-39).

Polymorphism: HindIII identifies a 5-allele polymorphism with bands at $11.8 \mathrm{~kb}(\mathrm{~A} 1), 10.9 \mathrm{~kb}(\mathrm{~A} 2), 9.3 \mathrm{~kb}$ (A3), $8.9 \mathrm{~kb}$ (A4), $8.1 \mathrm{~kb}$ (A5).

Frequency: Estimated from 31 unrelated individuals:

A1: 0.23

A2: 0.35

A3: 0.24

$\mathrm{PIC}=0.71$

A4: 0.10

A5: 0.08

Not Polymorphic For: MspI, PstI.

Chromosomal Localization: The human IFNAR gene maps to 21q22.1 (2).

Mendelian Inheritance: Co-dominant segregation of the HindIII RFLP was observed in a three-generation family in which 17 individuals were typed (11 informative meioses).

Probe Availability: The probe will be submitted to the American Tissue Culture Collection (ATCC). Until it is available through the ATCC, it can be obtained from E.V.

Acknowledgements: We thank Dr Ion Gresser for his constant encouragement, Dr Jean Weissenbach, Dr Christine Petit and Dr Jacqueline Levilliers for help and for providing us with human DNA samples. This work was supported by grants from Association pour la Recherche sur le Cancer, Fondation pour la Recherche Médicale, Centre National de la Recherche Scientifique, DRET 89-34-132, ANVAR 8906303 QAT.

References: 1) Uzé,G., Lutfalla,G. and Gresser,I. (1990) Cell 60, 225-234. 2) Lutfalla,G., Roeckel,N., Mogensen,K.E., Mattei,M.G. and Uzé,G. J. Interferon Res. 1990, in press.

\section{A Pstl polymorphism at the D5S39 locus}

S.Abdelhak, J.Melki, M.F.Bachelot, P.Burlet, P.Sheth, J.Frézal and A.Munnich

Unité de Recherches sur les Handicaps Génétiques de

I'Enfant, INSERM U-12, Hôpital des Enfants-Malades, 149

rue de Sèvres, 75743 Paris Cedex 15, France

Source/Description: Probe p105-153 Ra (D5S39) is a $4 \mathrm{~kb}$ fragment cloned into the EcoRI site of PUC8, isolated from a human genomic library (1).

Polymorphism: PstI identifies a two-allele polymorphism $\left(\mathrm{C}_{1}\right.$ : $\left.3.5 ; \mathrm{C}_{2}: 3.2\right)$ in addition to the two-allele polymorphisms described with MspI and XbaI (2).

Frequency: The allele frequencies were estimated from 50 unrelated individuals.

$\mathrm{C}_{1}: 0.20$

$\mathrm{C}_{2}: 0.80$

Not Polymorphic For: PvuII, TaqI, BglII, RsaI.

Chromosomal Localization: This probe has been assigned to 5q12-q14 (using linkage analysis) (1-2).

Mendelian Inheritance: Co-dominant segregation demonstrated in 5 families.

Availability: ATCC.

Other Comments: This probe has recently been shown to be tightly linked to the SMA locus (3). The use of the three enzymes MspI, XbaI, PstI increases the number of informative meioses.

References: 1) Alitalo,T. et al. (1987) Cytogenet. Cell Genet. 46, 570. 2) Leppert,M. et al. (1987) Cytogenet. Cell Genet. 46, 649. 3) Melki,J. et al. (1990) Nature 344, 767-768.

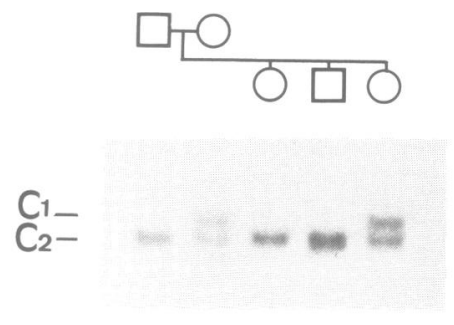

